\title{
Overview of Glacial Atlantic Ocean Mapping (GLAMAP 2000)
}

\author{
M. Sarnthein, ${ }^{1}$ R. Gersonde, ${ }^{2}$ S. Niebler, ${ }^{3}$ U. Pflaumann, ${ }^{1}$ R. Spielhagen, ${ }^{4}$ \\ J. Thiede, ${ }^{2,4}$ G. Wefer, ${ }^{3}$ and M. Weinelt ${ }^{1}$ \\ Received 2 July 2002; revised 11 September 2002; accepted 20 February 2003; published 3 May 2003.
}

[1] GLAMAP 2000 presents new reconstructions of the Atlantic's sea surface temperatures (SST) at the Last Glacial Maximum (LGM), defined at both 21,500-18,000 years B.P. ("Last Isotope Maximum") and 23,00019,000 years B.P. (maximum glacial sea level low stand and orbital minimum of solar insolation; EPILOG working group; see Mix et al. [2001]). These reconstructions use 275 sediment cores between the North Pole and $60^{\circ} \mathrm{S}$ with carefully defined chronostratigraphies. Four categories of core quality are distinguished. More than 100 core sections provide a glacial record with subcentennial- to multicentennial-scale resolution. SST estimates are based on a new set of almost 1000 reference samples of modern planktic foraminifera and on improved transfer-function techniques to deduce SST from census counts of microfossils, including radiolarians and diatoms. New proxies also serve to deduce sea ice boundaries. The GLAMAP 2000 SST patterns differ significantly in crucial regions from the CLIMAP [1981] reconstruction and thus are important in providing updated boundary conditions to initiate and validate computational models for climate prediction. INDEX TERMS: 4267 Oceanography: General: Paleoceanography; 3344 Meteorology and Atmospheric Dynamics: Paleoclimatology; 5415 Planetology: Solid Surface Planets: Erosion and weathering; KEYWORDS: Last Glacial Maximum, sea surface temperature reconstruction, paleoceanography, time slice definition, accuracy of age control

Citation: Sarnthein, M., R. Gersonde, S. Niebler, U. Pflaumann, R. Spielhagen, J. Thiede, G. Wefer, and M. Weinelt, Overview of Glacial Atlantic Ocean Mapping (GLAMAP 2000), Paleoceanography, 18(2), 1030, doi:10.1029/2002PA000769, 2003.

\section{Introduction}

[2] The broad meridional and narrow zonal extension of the Atlantic from high southern to high northern latitudes is a major factor in forcing the thermohaline circulation (THC) of the global ocean (model of Toggweiler and Samuel [1998]) and the climate system of the adjacent continents. The specific configuration of the Atlantic margins results in a strong advection of warm surface water into northern high latitudes. The cooling of this surface water which is more saline than anywhere else in high-latitude oceans triggers extensive deep water formation in the Nordic Seas, and thus drives the onset of global deep water circulation and drives the cross-equatorial heat transfer today characteristic of the Atlantic [Schmitz, 1995]. Different from the North Atlantic, the modern South Atlantic is characterized by the lateral incursion of surface currents, in the southeast by the advection of warm surface water from the Indian Ocean via a seasonal extension of the Agulhas Current, and in the southwest by the incursion of the cold Antarctic Circumpolar Current (overview of Berger and Wefer [1996]).

[3] Sea surface temperatures (SST) of the Last Glacial Maximum (LGM) reflect the most recent scenario of full glaciation in the Pleistocene [Teller, 1987; Svendsen et al., 1999]. Accordingly, the LGM is considered a well defined

\footnotetext{
${ }^{1}$ Institut für Geowissenschaften, University of Kiel, Kiel, Germany

${ }^{2}$ Alfred Wegener Institut, Bremerhaven, Germany.

${ }^{3}$ Fachbereich Geowissenschaften, University of Bremen, Germany.

${ }^{4}$ Geomar Kiel, Kiel, Germany.
}

Copyright 2003 by the American Geophysical Union. 0883-8305/03/2002PA000769 climatic end-member of Quaternary global change, contrasting with the present conditions characterized by Northern Hemisphere ice sheets of only limited extent. LGM objectives of particular interest are to assess (1) high-latitude variations in sea ice cover, (2) the intensity of past deep water formation in the northern North Atlantic, (3) the amount and seasonality of cross-equatorial heat advection from the central and southern Atlantic into the Nordic Seas, and (4) the corresponding extent of the West Atlantic heat pool. Additional objectives include an evaluation of (5) the resulting directions and strength of major wind systems and of both equatorial and coastal upwelling, and (6) the structure and location of oceanic frontal systems of the Antarctic Circumpolar Current (ACC), and its relation to (7) the reduction and/or cessation of the Indian-Atlantic warm water path through the Agulhas current.

[4] In a pioneer approach, Climate Long-Range Investigation, Mapping, and Prediction (CLIMAP) presented for the first time distribution maps of seasonal SST of the LGM North Atlantic [McIntyre et al., 1976] and global ocean at "18 ${ }^{14} \mathrm{C}$ ka" [CLIMAP Project Members, 1976, 1981]. The glacial SST estimates were based on census data of various microfossil assemblages from deep sea sediment cores, census data that were calibrated to the SST of modern surface water via a set of transfer functions based on principle component analysis and a multiple regression approach, the Imbrie-Kipp technique (I-K technique) [Imbrie and Kipp, 1971; Kipp, 1976]. Over the last 20 years the CLIMAP-LGM temperature maps have provided the only consistent array of global boundary conditions different from today. They have formed a unique data set for initiating numerical ocean models which simulate past 
climates, and vice versa, for testing the output of coupled General Circulation Models (O-GCMs) with the potential of predicting future climate change.

[5] According to CLIMAP [1981], the glacial-to-interglacial SST anomalies barely exceed $-2( \pm 1.5)^{\circ} \mathrm{C}$ in the tropics. In equatorial upwelling regions they may have reached just in excess of $-4^{\circ} \mathrm{C}$. However, these low CLIMAP SST anomalies may be biased. They do not fit the various land-based paleotemperature data deduced from strongly lowered snow lines [Bowler et al., 1976] and major vegetation changes in the tropics [Frenzel et al., 1992; Rind and Peteet, 1985], as summarized by Anderson and Webb [1994]. Moreover, West Atlantic SST records deduced from $\mathrm{Sr} / \mathrm{Ca}$ and $\delta^{18} \mathrm{O}$ ratios in corals off Barbados [Guilderson et al., 1994] (though recently debated by Martin et al. [1999]) reveal LGM SST anomalies of $-5( \pm 0.5)^{\circ} \mathrm{C}$, which are much higher than those found for this region by CLIMAP [1981]. Likewise, a recent transfer-function approach using a CABFAC matrix of Pleistocene foraminiferal assemblages in ten core-top samples for SST calibration has resulted in tropical glacial temperatures which are lowered by up to $6^{\circ} \mathrm{C}$ in the "tongue" of the westward flowing equatorial current [Mix et al., 1999]. Accordingly, to help resolve this long-standing controversy about glacial tropical SSTs, a thorough revision of the transfer-function techniques using a truly broad matrix of modern core-top samples is required to reconstruct microfossil-based SSTs with a generally agreeable degree of reliability.

[6] A further controversy concerns the CLIMAP reconstruction of the Greenland-Icelandic-Norwegian Seas. Here CLIMAP [1981] proposed extremely low glacial SST and an annually persistent sea-ice coverage. However, this scenario is opposed to recent microfossil and stable isotope records which indicate at least seasonally ice-free conditions during the LGM [Hebbeln et al., 1994; Sarnthein et al., 1995; Weinelt et al., 1996].

[7] The German Glacial Atlantic Ocean Mapping (GLAMAP 2000) Project presents a collection of papers [Weinelt et al., 2003; Pflaumann et al., 2003; Nørgaard-Pedersen et al., 2003; Niebler et al., 2003; Gersonde et al., 2003; Sarnthein et al., 2003] that display various sets of new and rigorously revised seasonal SST estimates and other proxy data of sea surface conditions during the LGM. The proxy data are estimated from an array of 275 densely sampled, well preserved, and well dated marine sediment records from Atlantic sites between $60^{\circ} \mathrm{S}$ and $85^{\circ} \mathrm{N}$ (Figure 1) [cf. Vogelsang et al., 2001]. This close-meshed grid of sampling sites is sufficient to resolve past mesoscale structures in the surface ocean. Our reconstruction serves the purpose of constraining more precisely the actual range of glacial-to-interglacial SST and circulation changes in the entire Atlantic, and may help to reconcile the apparent discrepancies amongst tropical temperature records obtained from the sea surface and the adjacent continents, such as discussed by Mix et al. [1999]. Most importantly, the GLAMAP 2000 data set provides up-to-date boundary conditions and validation data for 3-D global circulation and climate models, first employed in the experiments of Grieger and Niebler [2003] and Paul and Schäfer-Neth [2003].

[8] As compared to CLIMAP [1981], our approach is based (1) on a more precise age definition and age control of the LGM time slice $(-\mathrm{s}),(2)$ on various new transfer techniques to deduce SST from microfossil census counts such as the Modern Analog Technique (MAT) (Hutson [1977]; similarity maximum-modern analog technique (SIMMAX-MAT); Pflaumann et al. [1996]), in addition to the I-K technique using log-transfer techniques [Zielinski et al., 1998] and improved statistical computer programs [Sieger et al., 1999], and (3) a more precise calibration of the microfaunal census data to modern SST at $10 \mathrm{~m}$ water depth from the "objectively analyzed" hydrographic data set of Levitus and Boyer [1994] of the entire Atlantic.

\section{Choice of the LGM Time Slice and Age Control}

[9] To permit isochronous sampling of the LGM Atlantic, the GLAMAP 2000 working group agreed (in May 1997) on using a joint definition of the LGM time slice, within which all SST estimates at each single site are averaged (without weighting). A first definition of the LGM chronozone is based on the "Last benthic oxygen Isotope Maximum" (LIM; N. J. Shackleton, second EPILOG conference, October 2000) in the Atlantic ocean and on maximum planktic $\delta^{18} \mathrm{O}$ values in the northern North Atlantic, assuming that these maxima correspond to a maximum volume of global ice sheets. In North Atlantic sediment records with decadal-to-centennial resolution [Sarnthein et al., 1995; Voelker, 1999; Mix et al., 1999; Weinelt et al., 2003], the LIM interval defined in this way shows almost stable $\delta^{18} \mathrm{O}$ values from $\sim 18$ to $15{ }^{14} \mathrm{C}$ ka (corrected for 400 years ${ }^{14} \mathrm{C}$ reservoir effect; or until 14.5 ${ }^{14} \mathrm{C} \mathrm{ka}$; N. J. Shackleton, personal communication, 2000), equal to $\sim 21,500$ to 18,000 calendar (cal) years B.P. or somewhat younger [Stuiver et al., 1998]. The LIM or GLAMAP 2000 time slice ends with the onset of the Heinrich-1 stadial event.

[10] In the western equatorial and South Atlantic, however, several sediment records pose an irreconcilable problem to this LGM definition. They instead show an earlier shift toward lighter planktic $\delta^{18} \mathrm{O}$ values during the LIM time slice in parallel with a lead in deglacial warming from 18 to $15{ }^{14} \mathrm{C}$ ka [Ruehlemann et al., 1999; Gersonde et al., 2003], thus documenting an interhemispheric contrast of climate trends during the late LGM.

[11] The international EPILOG working group produced a second, slightly older definition of the LGM chronozone

Figure 1. (opposite) Map of GLAMAP 2000 authors' areas of responsibility for stratigraphic and microfossil-based SST data (full dots): GEOMAR = Nørgaard-Pedersen et al. [2003] (open dots show cores with planktic $\delta^{18} \mathrm{O}$ records only); IfG = Pflaumann et al. [2003]; GeoB = Niebler et al. [2003] (open dots show supplementary data of Mix [1986]); AWI = Gersonde et al. [2003] (SST records deduced from siliceous microfossils are marked by asterisks). Thermal equator is hatched. 

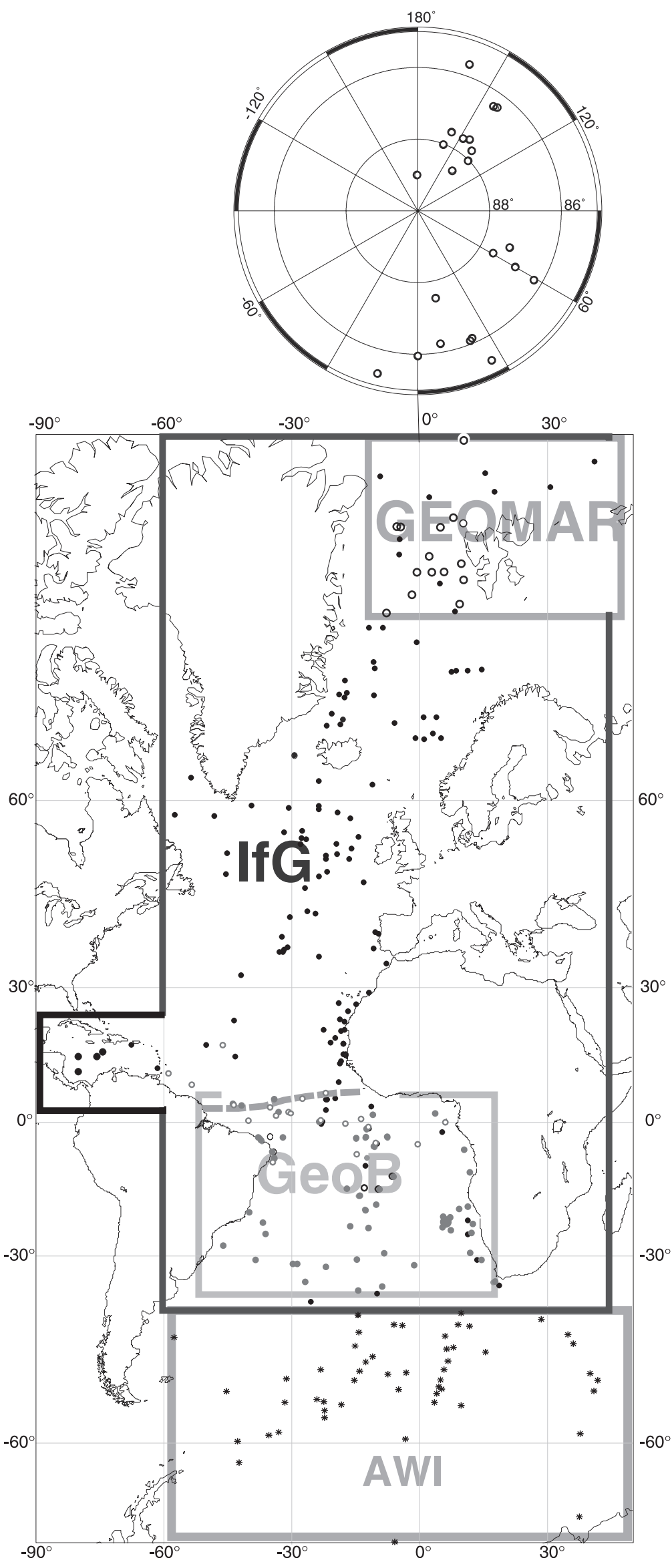
("Level 1") at $19.5-16.0{ }^{14} \mathrm{C} \mathrm{ka}$, equal to $23,000-19,000$ cal years B.P. (first conference in May 1999; Mix et al. [2001]). This definition is based on the insolation minimum at $65^{\circ}$ for summer near $21,000 \pm 2000$ cal years B.P. and on various paleoclimate records from the Atlantic, Antarctica, and Greenland. This alternative definition of the LGM gains support from evidence for the lowest glacial sea level stand on the north Australian shelf, which may reflect the maximum in global ice volume at $>18.0-16.5{ }^{14} \mathrm{C}$ ka [Yokoyama et al., 2000]. However, the extent and dating of this sea level low stand remain controversial, especially when compared with a recent sea level record from the nearby Sunda Shelf [Hanebuth et al., 2000].

[12] Acknowledging that slight differences in the LGM definition exist, some GLAMAP 2000 reconstructions employ for comparison both the GLAMAP 2000 and EPILOG age definition of the LGM, in part with interesting results [Pflaumann et al., 2003]. Moreover, Weinelt et al. [2003] discuss North Atlantic SST variability on decadal-tocentennial timescales over the entire glacial $\delta^{18} \mathrm{O}$ stage 2 $\left(25.6-12.0{ }^{14} \mathrm{C}\right.$ ka, equal to $29,000-14,000 \mathrm{cal}$ years ago). In the new GLAMAP 2000 reconstruction of North Atlantic SST [Pflaumann et al., 2003], the EPILOG "Level-1" time window was reduced to $22,500-19,000 \mathrm{cal}$ years B.P. to exclude the second warm episode of DO interstadial 2 which lasted from 23,700-22,000 cal years B.P. (based on the GISP2 timescale; Grootes and Stuiver [1997]). On the other hand, a final small warm excursion near 22,200 cal years was integrated in the reconstruction.

[13] The primary age control for the GLAMAP 2000 cores is based on $\delta^{18} \mathrm{O}$ stratigraphy. However, many cores from southern high latitudes do not provide a continuous $\delta^{18} \mathrm{O}$ stratigraphy. Here, abundance records of the radiolarian Cycladophora davisiana and/or of diatom species (e.g., Eucampia antarctica) are employed, the chronostratigraphy of which is time calibrated by $\delta^{18} \mathrm{O}$ records and AMS ${ }^{14} \mathrm{C}$ dating [Howard and Prell, 1992; Gersonde et al., 2003].

[14] More than one third of the sediment records are dated by AMS ${ }^{14} \mathrm{C}$ ages which are ${ }^{14} \mathrm{C}$ reservoir-corrected by $\sim 400$ years according to Stuiver et al. [1986] and Bard [1988]. The AMS ${ }^{14} \mathrm{C}$ ages have been converted to calendar ages by CALIB-1998 back to $\sim 18,000{ }^{14} \mathrm{C}$ years B.P. [Stuiver et al., 1998], and further back by tuning North Atlantic sediment records to the GISP2 timescale [Voelker et al., 1998; 2001]. Core sections without ${ }^{14} \mathrm{C}$ age control were correlated to ${ }^{14} \mathrm{C}$-dated neighbor cores by means of highresolution structures in the $\delta^{18} \mathrm{O}$ records. Stratigraphic details of $>120$ cores from the North and Central Atlantic are documented by Vogelsang et al. [2001].

\section{Differential Accuracy of Age Control}

[15] Our reconstructions only rely on core sections where the LGM interval was clearly identified in (largely published) $\delta^{18} \mathrm{O}$ curves or in siliceous microfossil records. On the basis of sediment accumulation rates, dating precision, and differential sampling and time resolution, the quality of our SST estimates varies from one site to another. According to the integrated effect of these variables on the SST estimates, we classified the marine sediment records into four categories [cf. Vogelsang et al., 2001].

[16] 1. Category-I cores comprise 133 well-dated sections with sedimentation rates of $>3 \mathrm{~cm} / \mathrm{ka}$ and sample spacings of $<5-10 \mathrm{~cm}$. Approximately $75 \%$ of Category-I cores have rates of $>5 \mathrm{~cm} / \mathrm{ka}, 15 \%$ of the cores have rates $>20 \mathrm{~cm} / \mathrm{ka}$. Category Ia: $50 \%$ of the Category-I records which are ${ }^{14} \mathrm{C}$ dated. Category Ib: Category-I cores, not ${ }^{14} \mathrm{C}$ dated.

[17] 2. Category II comprises 87 cores with sedimentation rates of $1.5-3.0 \mathrm{~cm} / \mathrm{ka}$, occasionally ${ }^{14} \mathrm{C}$ dated (Category IIa). Category IIb includes siliceous ooze sections from the Southern Ocean with medium to very high sedimentation rates $(>1.5$ to $>20 \mathrm{~cm} / \mathrm{ka})$, but lacking $\delta{ }^{18} \mathrm{O}$ and ${ }^{14} \mathrm{C}$ stratigraphy. In these core sections age control is based on defined structures in siliceous-microfossil abundance records [Gersonde et al., 2003].

[18] 3. Category III records (55 cores) show sedimentation rates of less than $1.5 \mathrm{~cm} / \mathrm{ka}$, a smoothed SST signal, and are occasionally ${ }^{14} \mathrm{C}$ dated. Here the densely sampled $\delta^{18} \mathrm{O}$ maxima and/or siliceous microfossil abundance records are generally adequate to define the position of the LGM via comparison with the records of neighbor sites. Cores of this quality category were employed to increase the spatial density of SST data from the Mid Atlantic ridge and in (Arctic) sea regions largely sea-ice covered, where sedimentation rates are generally low.

[19] 4. Category IV records, which have a poor $\delta^{18} \mathrm{O}$ stratigraphy, low sedimentation rates, and a smoothed SST signal, were rejected (and not included in the total of 275 records).

[20] The differential impact of bioturbational mixing, which is a function of the carbon/nutrient flux near the seafloor [Trauth et al, 1997], is not considered in this classification. Weinelt et al. [2003] present a special study of the intraLGM SST variability, also examining the effects of centennial-scale climate change in ultrahigh-resolution sediment cores.

\section{Reconstruction of Isotherms, Seasonality, and Temperature Anomalies}

[21] The GLAMAP 2000 paleotemperature reconstructions are based on nearly 1000 reference samples of modern planktic foraminifera counts in the Atlantic, and a number of different transfer techniques using microfossil (planktic foraminifers, diatoms, radiolarians) census data as described in this group papers [Gersonde et al., 2003; Niebler et al., 2003; Pflaumann et al., 2003; Weinelt et al., 2003]. Pertinent results from Uk37- and $\mathrm{Mg} / \mathrm{Ca}$-based SST estimates are discussed for comparison. In southern high latitudes (south of $\sim 40^{\circ} \mathrm{S}$ ), SST values were only reconstructed for (southern) summer because sediment trap data in this region suggest that microfossils and their signals are generated during summer only [Abelmann et al., 1999; Gersonde and Zielinski, 2000].

[22] In contouring the paleotemperature maps, the isolines were derived from strictly linear interpolations (triangulation) between SST estimates of the irregularly distributed neighbor sites. In rare cases of controversial SST estimates, Category-I data were preferred to Category-II and -III data, 
respectively. Minor deviations from the local SST average are considered to reflect a sort of cumulative standard error of sample analysis, laboratory counting, and stratigraphy. The results show that the LGM temperature estimates are internally highly consistent.

[23] Near to the equator, Pflaumann et al. [2003] ascribed the SST values of the "cold season" to Northern Hemisphere summer (i.e., to July-September) up to $5^{\circ} \mathrm{N}$, that is the latitude of the modern thermal equator (Figure 1). Similarly, warm SST up to $5^{\circ} \mathrm{N}$ were ascribed to Northern Hemisphere winter (January-March).

[24] Sea-ice margins were defined by various techniques with largely consistent results, as described in the papers of Gersonde et al. [2003], Sarnthein et al. [2003], NørgaardPedersen et al. [2003], and Pflaumann et al. [2003].

[25] Similar to CLIMAP [1981], maps of LGM temperature anomalies were constructed using a point-by-point subtraction of LGM SST estimates minus Modern SST of Levitus and Boyer [1994], which were interpolated from the $1^{\circ}$ by $1^{\circ}$ grid for each GLAMAP 2000 site. Seasonality maps of SST were derived from the subtraction of caloric summer and winter SST values. The difference maps between the GLAMAP 2000 and CLIMAP reconstructions of the LGM SST patterns in the Atlantic were deduced from interpolating the GLAMAP 2000 sites into the CLIMAP
SST distribution pattern using several different techniques which are described in detail in the papers on the different regions of the Atlantic. The complete data set of the GLAMAP 2000 project is available from the PANGAEA paleoclimate databank (http//www.pangaea.de) and will be summarized by the GLAMAP 2000 Project Members in a separate paper (GLAMAP 2000 Project Members, manuscript in preparation, 2003).

[26] Acknowledgments. This group of papers on the LGM represents studies of the GLAMAP 2000 Project, funded as synthesis of the National Climate Project by the German Ministry of Research (BMBF) 1996 to early 2000. We also acknowledge long-standing support from the German Science Foundation (DFG) in the framework of the Special Research Projects (Sonderforschungsbereich) 261 and 313 in Bremen and Kiel and various other smaller proposals. This reconstruction of Atlantic sea surface temperatures is part of the synthesis efforts of the International Marine Studies of Past Global Change (IMAGES) program. The reconstruction is based on broad data sets which strongly gained in number and quality from helpful cooperation and critical remarks of many colleagues outside Germany, who contributed significantly to these results by adding valuable data and critical discussion (in particular, J.-C. Duplessy and L. Labeyrie, Gif-sur-Yvette; M. Chapman and N. J. Shackleton, Cambridge; J.-L. Turon and J. Duprat, Bordeaux; A. Mix, Corvallis, OR; E. Jansen, Bergen; A. deVernal, Montreal; and former members of the CLIMAP project at Lamont-Doherty Earth Observatory, Palisades, NY). L. Peterson, Miami, FL, kindly supported the publication of our papers in Paleoceanography as editor.

\section{References}

Abelmann, A., U. Brathauer, R. Gersonde, R. Sieger, and U. Zielinski, Radiolarian-based transfer function for the estimation of sea surface temperatures in the Southern Ocean (Atlantic sector), Paleoceanography, 14, 410-421, 1999.

Anderson, D. M., and R. S. Webb, Ice-age tropics revisited, Nature, 367, 23-24, 1994.

Bard, E., Correction of AMS-14C ages measured in planktonic foraminifera: Paleoceanographic implications, Paleoceanography, 3, 635-646, 1988.

Berger, W. H., and G. Wefer, Expeditions into the past: Paleoceanograpic studies of the South Atlantic, in The South Atlantic, edited by G. Wefer et al., pp. 363-410, Springer-Verlag, New York, 1996.

Bowler, J. M., G. S. Hope, J. N. Jennings, G. S. Singh, and D. Walker, Late Quaternary climates of Australia and New Guinea, Quat. Res., 6, 359-394, 1976

CLIMAP Project Members, The surface of the ice-age Earth, Science, 191, 1131-1137, 1976.

CLIMAP Project Members, Seasonal reconstructions of the Earth's surface at the Last Glacial Maximum, Geol. Soc. Am. Map Chart Ser., $M C$-36, Lamont-Doherty Geol. Obs., Columbia Univ., Palisades, New York, 1981.

Frenzel, B., M. Pécsi, and A. A. Velichko (Eds.), Atlas of Paleoclimates and Paleoenvironments of the Northern Hemisphere: Late Pleistocene, Holocene, pp. 1-153, G. Fischer, New York, 1992.

Gersonde, R., and U. Zielinski, The reconstruction of late Quaternary Antarctic sea-ice distribution-The use of diatoms as a proxy for seaice, Palaeogeogr. Palaeoclimatol. Palaeoecol., 162, 263-286, 2000.

Gersonde, R., et al., Last glacial sea surface temperature and sea-ice extent in the Southern Ocean (Atlantic-Indian sector) - A multi- proxy approach, Paleoceanography, 18 , doi:10.10292002PA000809, in press, 2003.

Grieger, B., and H.-S. Niebler, Glacial South Atlantic surface temperatures interpolated with a semi-inverse ocean model, Paleoceanography, 18, 1, doi:10.1029/2002PA000773, in press, 2003

Grootes, P. M., and M. Stuiver, Oxygen 18/16 variability in Greenland snow and ice with $10^{-3}$ to $10^{5}$-year resolution, J. Geophys. Res., 102, 26,455-26,470, 1997.

Guilderson, T., R. Fairbanks, and J. L. Rubenstone, Tropical temperature variations since 20,000 years ago: Modulating interhemispheric climate change, Science, 263, 663665, 1994.

Hanebuth, T., K. Stattegger, and P. M. Grootes, Rapid flooding of the Sunda shelf: A late-glacial sea-level record, Science, 288, $1033-$ $1035,2000$.

Hebbeln, D., T. Dokken, E. S. Andersen, M Hald, and A. Elverhoi, Moisture supply for northern ice-sheet growth during the last glacial Maximum, Nature, 370, 357-360, 1994.

Howard, W. R., and W. L. Prell, Late Quaternary surface circulation of the southern Indian Ocean and its relationship to orbital variations, Paleoceanography, 7, 79-117, 1992.

Hutson, W. H., Transfer functions under no-analog conditions: Experiments with Indian Ocean planktonic foraminifera, Quat. Res., 8, 355367, 1977.

Imbrie, J., and N. G. Kipp, A new micropaleontological method for quantitative paleoclimatology: Application to a late Pleistocene Caribbean core, in The late Cenozoic Glacial Ages, edited by K. K. Turekian, pp. 71-181, Yale Univ. Press, New York, 1971.

Kipp, N. G., New transfer function for estimating past sea-surface conditions from sea-bed distribution of planktonic foraminiferal assemblages in the North Atlantic, in Investigation of Late Quaternary Paleoceanography and Paleoclimatology, vol. 145, Geol. Soc. Am. Mem., edited by R. M. Cline and J. D. Hays, pp. 3-42, Geol. Soc. of Am., Boulder, Colo., 1976.

Levitus, S., and T. Boyer, World Ocean Atlas, vol. 4, Temperature, U. S. Dept. of Comm., Washington, D. C., 1994.

Martin, P. A., D. W. Lea, T. A. Mashiotta, T. Papenfuss, and M. Sarnthein, Variation of foraminferal $\mathrm{Sr} / \mathrm{Ca}$ over Quaternary glacial-interglacial cycles: Evidence for changes in mean ocean $\mathrm{Sr} / \mathrm{Ca}$ ?, Geochem. Geophys. Geosyst., 1, doi:10.1029/1999GC000006, 1999.

McIntyre, A., N. G. Kipp, A. W. H. Bé, T. Crowley, T. Kellogg, J. V. Gardner, W. Prell, and W. F. Ruddiman, Glacial North Atlantic 18,000 years ago, Geol. Soc. Am. Mem., 145, $43-$ 76, 1976.

Mix, A. C., Late Quaternary paleoceanography of the Atlantic Ocean: Foraminiferal fauna and stable isotope evidence, $\mathrm{PhD}$ thesis, Columbia Univ., New York, 1986.

Mix, A. C., A. E. Morey, N. G. Pisias, and S. W. Hostetler, Foraminiferal faunal estimates of paleotemperature: Circumventing the no-analog problem yields cool ice age tropics, Paleoceanography, 14, 350-359, 1999.

Mix, A. C., E. Bard, and R. Schneider, Environmental processes of the Ice age: Land, oceans, glaciers (EPILOG), Quat. Sci. Rev., 20, $627-$ 658, 2001.

Niebler, H.-S., S. Mulitza, B. Donner, H. Arz, J. Pätzold, and G. Wefer, Sea surface temperatures in the equatorial and South Atlantic ocean during the Last Glacial Maximum (23$19 \mathrm{ka})$, Paleoceanography, 18, doi:10.1029/ 2002PA000577, in press, 2003.

Nørgaard-Pedersen, N., et al., The Arctic Ocean during the Last Glacial Maximum: Atlantic and Polar domains of surface water mass distribution and ice cover, Paleoceanography, 18, doi:10.1029/2002PA00000781, in press, 2003. 
Paul, A., and C. Schäfer-Neth, Glacial water masses in a global ocean model, Paleoceanography, 18, doi:10.1029/2002PA000783, in press, 2003.

Pflaumann, U., J. Duprat, C. Pujol, and L. D. Labeyrie, SIMMAX: A modern analog technique to deduce Atlantic sea surface temperatures from planktonic foraminifera in deep sea sediments, Paleoceanography, 11, 15-35, 1996.

Pflaumann, U., et al., The Glacial North Atlantic: Sea surface conditions reconstructed by GLAMAP 2000, Paleoceanography, 18 , doi:10.1029/2002PA000774, in press, 2003

Rind, D., and D. Peteet, Terrestrial conditions at the last glacial maximum and CLIMAP surface temperature estimations: Are they consistent?, Quat. Res., 24, 1-22, 1985.

Ruehlemann, C., S. Mulitza, P. J. Müller, G. Wefer, and R. Zahn, Warming of the tropical Atlantic ocean and slowdown of thermohaline circulation during the last deglaciation, Nature, 402, 511-514, 1999.

Sarnthein, M., et al., Variations in Atlantic surface ocean paleoceanography, $50-80 \mathrm{~N}$ : A time-slice record of the last 30,000 years, Paleoceanography, 10, 1063-1094, 1995.

Sarnthein, M., U. Pflaumann, and M. Weinelt, Past extent of sea ice in the northern North Atlantic inferred from foraminiferal paleotemperature estimates, Paleoceanography, 18, doi:10.1029/2002PA000771, in press, 2003.

Schmitz, W. J., On the interbasin-scale thermohaline circulation, Rev Geophys., 33, 151173, 1995.

Sieger, R., R. Gersonde, and U. Zieliski, A new extended software package for quantitative paleoenvironmental reconstructions, Eos Trans. $A G U, 80(19), 223,1999$.

Stuiver, M., G. W. Pearson, and T. F. Braziunas, Radiocarbon age calibration of marine samples back to 9000 cal yr BP, Radiocarbon, 28, 980-1021, 1986.

Stuiver, M., P. J. Reimer, and T. F. Braziunas, High-precision radiocarbon age calibration for terrestrial and marine samples, Radiocarbon, 40, 1127-1152, 1998.

Svendsen, J. I., et al., Maximum extent of the Eurasian ice sheets in the Barents and Kara Sea region during the Weichselian, Boreas, $28,234-242,1999$.

Teller, J. T., Proglacial lakes and the southern margin of the Laurentide ice sheet, Geol. N Am., K-3, 37-70, 1987.

Toggweiler, J. R., and B. Samuel, Energizing the Oceans' large-scale circulation for climate change, paper presented at Chapman Conference: Mechanisms of Millennial-Scale Globa Climate Change, Snowbird, Utah, AGU, Washington, D. C., 1998.

Trauth, M. H., M. Sarnthein, and M. Arnold, Bioturbational mixing depth and carbon flux at the seafloor, Paleoceanography, 12, 517526, 1997.

Voelker, A. H. L., Zur Deutung der DansgaardOeschger Ereignisse in ultra-hochauflösenden Sedimentprofilen aus dem Europäischen Nordmeer, Ber. Rep. Inst. Geowiss. Univ. Kiel, 9, 1-180, 1999 .

Voelker, A. H. L., M. Sarnthein, P. M. Grootes, H. Erlenkeuser, C. Laj, A. Mazaud, M. J. Nadeau, and M. Schleicher, Correlation of marine C-14 ages from the Nordic Seas with the GISP2 isotope record: Implications for C-14 calibration beyond 25 ka BP, Radiocarbon, 40, 517-534, 1998

Voelker, A. H. L., P. M. Grootes, M. J. Nadeau, and M. Sarnthein, ${ }^{14} \mathrm{C}$ levels in the Iceland Sea from $25-53 \mathrm{kyr}$ and their link to the Earth's magnetic field intensity, Radiocarbon, 42, 437-452, 2001

Vogelsang, E., M. Sarnthein, U. Pflaumann, $\delta^{18} \mathrm{O}$ stratigraphy, chronology, and sea surface tem- peratures of Atlantic sediment records (GLAMAP-2000 Kiel), Ber. Rep. Inst. Geowiss. Univ. Kiel, 13, 1-13, 244, 2001.

Weinelt, M., M. Sarnthein, U. Pflaumann, H. Schulz, and S. Jung, Ice-free Nordic Seas during the Last Glacial Maximum?-Potential sites of deepwater formation, Paleoclim. Data Modell., 1, 283-309, 1996.

Weinelt, M., E. Vogelsang, M. Kucera, U. Pflaumann, M. Sarnthein, A. Völker, and H. Erlenkeuser, Variability of North Atlantic heat transfer during MIS 2, Paleoceanography, 18, doi:10.1029/2002PA000772, in press 2003.

Yokoyama, Y., K. Lambeck, P. deDekker, P. Johnston, and K. Fifield, Timing of the Last Glacial Maximum from observed sea-level minima, Nature, 406, 713-716, 2000

Zielinski, U., R. Gersonde, R. Sieger, and D. Fütterer, Quaternary surface water temperature estimations: Calibration of a diatom transfer function for the Southern Ocean, Paleoceanography, 13, 365-383, 1998.

R. Gersonde and J. Thiede, Alfred Wegener Institut, Postfach 120161, D-27570 Bremerhaven, Germany. (gersonde@AWI-Bremerhaven. de; jthiede@awi-bremerhaven.de)

U. Pflaumann, M. Sarnthein, and M. Weinelt, Institut fuer Geowissenschaften, University of Kiel, Olshausenstr. 40, D-24098 Kiel, Germany. (up@gpi.uni-kiel.de; ms@gpi.uni-kiel.de; mw@ gpi.uni-kiel.de)

S. Niebler and G. Wefer, Fachbereich Geowissenschaften, Postfach 330440, University of Bremen, D-28334 Bremen, Germany. (niebler@ uni-bremen.de; gwefer@zfn.uni-bremen.de)

R. Spielhagen, Geomar, Wischhofstr. 1-3, D-24148 Kiel, Germany. (rspielhagen@geomar. de) 